\title{
THE AROMANIAN-ROMANIAN NATIONAL MOVEMENT (1859-1905): AN ANALYTICAL MODEL
}

\author{
VLADIMIR CREȚULESCU
}

\begin{abstract}
At the turn of the $20^{\text {th }}$ century, Macedonia was a region still controlled by the waning Ottoman Empire, though intensely coveted by the neighbouring Balkan states, which deployed national propaganda movements in Macedonia, in preparation for future territorial annexations. It is this author's contention that the "Macedonian question" thus engendered gives rise to several overlapping triadic configurations of interlocking, interacting and mutually monitoring nationalisms, as per the analytical model put forth by Rogers Brubaker. Working on this premise, and after adjusting Brubaker's model to account for the specific relational settings of the Macedonian question, this author proceeds to draft a case study of a specific triadic configuration, among several operating in fin-de-siècle Macedonia: namely, the one arisen out of the mutual monitoring and interaction of a Romanian nationalizing nationalism, a Greek nationalizing nationalism, and two Aromanian (or Vlach) minority nationalisms.
\end{abstract}

Vladimir Crețulescu, PhD student, University of Bucharest, Romania, University of Bordeaux, France, e-mail: vladimir_cretulescu@yahoo.com

Key words: the Macedonian question, nationalizing nationalism, national minority nationalism, political field.

DOI: http://dx.doi.org/10.14746/bp.2015.22.8

\section{POLITICAL CONTEXT: MACEDONIA AT THE TURN OF THE $20^{\mathrm{TH}}$ CENTURY - THE BALKAN PRIZE}

Macedonia was, at the beginning of the $20^{\text {th }}$ century, still part of a waning Ottoman Empire. It was also intensely coveted by all of the neighbouring Christian Balkan states. But what exactly made Macedonia so attractive to its Christian neighbours? And, more importantly still, what was commonly understood at the time by the word 'Macedonia'?

It is important to remember that, in the time-frame which concerns the present paper (i.e. the latter $19^{\text {th }}$ century - early $20^{\text {th }}$ century), the term 'Macedonia' referred to a rather vaguely delimited geographical entity, which, broadly speaking, bordered on Mount Olympus, the Pindus Mountains and the Aegean to the South, the Šar Mountains ( $\breve{S} a r$ Planina) to the North, The Rhodope Mountains to the East and

${ }^{1}$ This paper is supported by the Sectorial Operational Programme Human Resources Development (SOP HRD), financed from the European Social Fund and by the Romanian Government under the contract number SOP HRD/159/1.5/S/136077. 
Lake Ohrid to the West; the modern $\left(19^{\text {th }}\right.$ century) use of the term 'Macedonia' originated with western-European geographers, its most direct political reference being Philip II's ancient kingdom of Macedonia ${ }^{1}$. In other words, the modern use of the term was purely geographical, since there was no contemporary political or administrative entity corresponding to it ${ }^{2}$.

Though economically poor, Macedonia possessed great geo-strategic significance. Firstly, it was traversed by several important trade routes: the route from the Danube to the Aegean Sea streamed South through the valley of the River Vardar; the Sofia basin communicated with the Aegean through the valley of the river Struma; and, of course, there was also the ancient Egnatian road, which linked the Adriatic and Aegean seas, passing through the towns of Ohrid, Bitolia and Florina ${ }^{3}$. Secondly, all this trade flowed, in one way or another, to the great port of Salonica, which was the economic and commercial nexus of the whole region. This was the second largest city of European Turkey, superseded only by Constantinople.

Finally, Macedonia's proximity to the Bosphorus and Dardanelles made it strategically important in the eyes of the Great Powers: it would have been a great staging area for any power seeking to seize control of all traffic and trade between the Black Sea and the Mediterranean.

Small wonder, then, that all the neighbouring states were vying for control of Macedonia: the nation that controlled it would become the local hegemonic power of the Balkans.

Before attempting any territorial annexation however, the Balkan states would need to justify taking such drastic action; the ideological tool required for the job was the principle of nationalities ${ }^{4}$; historically the cornerstone of national statehood - particularly in East and Central Europe -, this principle stipulated that every ethno-national community had the right to possess its own nation-state, and that conversely, each nation-state should overlap, as far as possible, with the territorial distribution of its corresponding ethno-national community. On this ideological basis, if a Balkan

\footnotetext{
${ }^{1}$ Georges Castellan, Histoire des Balkans XIVe-Xxe siècle (Fayard, 1991), 350.

${ }^{2}$ From the perspective of the Ottoman territorial administration, Macedonia spanned over the vilayets ("counties") of Selanik and Bitolia, the sandjak of Servia, and parts of the vilayet of Kossovo; see Castellan, Histoire des Balkans, 350.

${ }^{3}$ Ibid., 351.

${ }^{4}$ According to Eric Hobsbawm, the principle of nationalities, as formulated in the classical phase of European nationalisms (i.e. circa 1830 - 1870), is characterized by the following five features: an emphasis on the idea of linguistic and cultural community (1); the emphasis on nationalisms that seek to form a new state or take control of an existing one, as opposed to the nationalisms of already established nationstates (2); a historicity driven by a sense of historical mission (3); a claim of descent from the 1879 French revolution (4); and lastly, a certain conceptual ambiguity, to be found in both the discourse and terminology employed (5); Eric Hobsbawm, Nations et nationalisme depuis 1780, trans. Dominique Peters (Paris: Gallimard, 1992), 131-132.
} 
state managed to prove that a sizable portion of Macedonia's population was composed of fellow nationals, it would, in theory, be entitled to annex that portion of Macedonian territory inhabited mainly by its national population.

Applying the principle of nationalities to Macedonia would prove no simple task, however. Due to the poverty and social backwardness of the region, most of the illiterate peasantry that formed the bulk of the Macedonian population had, by the mid$19^{\text {th }}$ century, not yet developed any national consciousness ${ }^{5}$. This can hardly be held against it, if we consider the fact that the Ottoman Empire as a whole was operating on a pre-national conception of demography, with its roots in Islamic law. For instance, whenever the Ottoman authorities ordered a census, the population was classified on religious grounds (as per the medieval millet system), rather than national ones ${ }^{6}$.

All this, though inconvenient, would not stop the Balkan nations from reaching their goals. If the national idea had not yet entered Ottoman Macedonia, the task at hand was that of instilling a sense of national belonging in the local populace - by gentle persuasion (read 'cultural propaganda'), or, if need be, by force.

The great ethnic and cultural diversity of the Macedonian population certainly offered ample room for the formulation and propagation of multiple competing national ideologies: the region's inhabitants formed an ethnic jumble of Slavs, Greeks, Turks, Vlachs, Albanians, Gypsies and Sephardic Jews (the latter concentrated mainly in and around Salonica). And that's just counting the broad ethnic groupings, religious and cultural subdivisions notwithstanding ${ }^{7}$.

In order to organize and coordinate the national indoctrination of the Macedonians, state-funded national cultural organizations needed to be set up. In 1884, the Bulgarians founded the Cyril and Methodius Society, followed shortly thereafter by the Serbs, who created the Saint Sava Society in $1886^{8}$. The Greeks had no need to create a new institution, as they already had the powerful and influential Patriarchate

\footnotetext{
${ }^{5}$ Max Demeter Peyfuss, "Aromânii în era naționalismelor balcanice" ["The Aromanians in the Era of Balkan Nationalisms"], in Aromânii: istorie, limbă, destin [The Aromanians: History, Language, Destiny], ed. Neagu Djuvara (Bucureşti: Humanitas, 2012), 177; it should be noted that, in keeping with the theoretical thinking of anthropologist Paul Brass, I draw a sharp distinction between ethnic identity or ethnicity (which mobilizes symbolic and emblematic markers to define the internal and external boundaries of a group), and national identity (which entails the making of political claims based on ethnicity, which in turn, when accepted by a state, promote the claimant ethnic community to the status of a national community); see Paul Brass, Ethnicity and Nationalism, Theory and Comparison (New Dehli: Sage Publications, 1991), 19-20; on the construction of ethnic identity see also Fredrik Barth, ed., Ethnic Groups and Boundaries: The Social Organization of Culture Difference (London: Allen \& Unwin, 1969); therefore in stating that the Macedonian population was, by the mid- $19^{\text {th }}$ century, still devoid of any national identity, I by no means rule out the existence of strong ethnic identifications (such as the Aromanian one, for instance). I merely maintain that no claim of political rights had as of yet been made based on such ethnic identities.

${ }^{6}$ See Stanford j. Shaw and E.K. Shaw, History of the Ottoman Empire and Modern Turkey, vol. II (Cambridge University Press, 1976 and 1977), 208.

${ }^{7}$ See Castellan, Histoire des Balkans, 352.

${ }^{8}$ Barbara Jevalich, Istoria Balcanilor [History of the Balkans], vol. II (Iaşi: Institutul European, 2000), 91.
} 
of Constantinople (which was, for all intents and purposes, a national Greek organization). However, from 1870 onwards the Greek Patriarchate would have to contend with a rival (and equally national) ecclesiastical institution: the Bulgarian Exarchate. The Exarchate's ultimate aim was to extend its sway over all the Macedonian Slavs, and thus win them over for the Bulgarian national cause.

\section{ROGERS BRUBAKER'S TRIADIC MODEL. ITS APPLICATION TO THE "MACEDONIAN QUESTION"}

I have, up to the present point, given a summary account of Macedonia's valorization as a focus of intense competition between the Balkan States, throughout the latter half of the $19^{\text {th }}$ and early $20^{\text {th }}$ centuries. This tense political situation is known to contemporary diplomatic circles as "the Macedonian Question".

At first glance, the "Macedonian Question" appears as an open-and-shut affair: a question of straightforward international rivalry between young nation-states possessed of opposed political and national interests. However, Rogers Brubaker contends that in adopting such simplistic views on the interrelated workings of nationalisms, one misses much of the phenomenon's complexity.

Brubaker posits that in situations where two nation-states are vying for a contested territory and/or for authority over a given population, there is always an additional element to be taken into consideration; one that usually goes unnoticed. Namely, the ethno-national minority caught in the middle of the struggle.

To account for this additional element, Brubaker elaborates a new model for analyzing the manner in which nationalisms interact. In his view, interactions between nationalisms are not dyadic, but triadic. That is to say, they always involve three interlocking, interrelated and mutually monitoring types of nationalism, namely: (1) the internal, "nationalizing" nationalism of a newly independent (or newly reconfigured) state; (2) the external, trans-border nationalism of what Brubaker terms "external national homelands"; and (3) the nationalism of a national minority9.

Nationalizing nationalisms (1) are, according to Brubaker, manifest in newly created nation-states ${ }^{10}$. Such nationalisms make claims in the name of the "core nation" of the state. This nation is conceived in ethno-cultural terms, and sharply distinguished from the citizenry as a whole. Though dominant, the core nation is perceived as occupying a weak cultural, economic or demographical position within the state - the presumed legacy of the oppression it was subject to before the attainment of national independence. Therefore, remedial action is called for: the state apparatus

\footnotetext{
${ }^{9}$ See Rogers Brubaker, Nationalism Reframed: Nationhood and the National Question in the New Europe (Cambridge: Cambridge University Press, 1996), 4-6, 8.

${ }^{10}$ For a detailed account of the workings of nationalizing nationalisms, see Brubaker, Nationalism Reframed, 63-66.
} 
acts as an instrument for the promotion of the dominant nation's culture, interests and goals; all minority ethnic groups and cultures within the state are to be assimilated to the said dominant culture, subsumed to said interests and goals. All this is hardly surprising, since the state is seen as functioning to the exclusive benefit of the dominant ethnic nation, which is, in effect, construed as the state's "owner".

"External national homeland" nationalisms (2), on the other hand, assert a nation's right, even obligation to protect the interests and see to the welfare of ethno-national kin found outside the borders of the nation-state; that is to say, in other, neighbouring, countries ${ }^{11}$. As such, "national homeland" nationalisms are set in direct opposition to the nationalizing nationalisms of neighbouring states. They seek to protect "their" external ethnic communities from what they see as the de-nationalizing policies of neighbouring nationalizing nationalisms. "Homeland" nationalisms typically set ethno-national bonds above civic ties such as citizenship. Such a view fully justifies a nation-states' involvement in matters concerning external "ethno-national kin" who are not its citizens, but the citizens of other states ${ }^{12}$.

National minority nationalisms (3) typically find themselves caught between the stances of the two aforementioned nationalisms ${ }^{13}$. This however constitutes, according to Brubaker, a third type of nationalism, autonomous in relation to the other two aforementioned, mutually antagonistic types. Minority nationalisms make political claims in the name of the minority group, which is self-understood in national, rather than simply ethnic terms. Such political claims range anywhere, from varying forms of cultural, educational or religious autonomy, to full independence. Though minority nationalisms (3) and "homeland" nationalisms (2) both define themselves in opposition to a nationalizing nationalism (1) - which thus becomes their common enemy - this does not imply that minority and homeland interests are identical, or that corresponding minority and homeland nationalisms are perfectly aligned. Indeed, their interests and outlooks may differ considerably.

Brubaker insists upon the fact that each of the three types of nationalism described designates "a political stance, not an ethnographic fact"14. That is to say, nationalizing, homeland, and minority nationalisms are to be understood as mutually interacting, mutually monitoring political fields (in the bourdeusian sense) ${ }^{15}$, interlocked in

${ }^{11}$ For a detailed account of the workings of external "homeland" nationalisms, see Ibid., 66-67.

12 Brubaker clearly specifies that the term "homeland nationalism" does not imply the target external minority's ever having resided within the territory of the "homeland" nation. Nor does it imply that the external minority in question originated geographically from the territory of the "homeland" nation. The claim of "homeland nationalisms" is to ethnic and cultural kinship with the external minority in question, with no relation to the minority's territorial origins; see Brubaker, Nationalism Reframed, 58.

${ }^{13}$ For a detailed account of the workings of national minority nationalisms, see Ibid., 60-62.

${ }^{14}$ Ibid., 5.

15 Pierre Bourdieu defines the field as "une configuration de relations objectives entre des positions [...] définies objectivement [...] par leur situation (situs) actuelle et potentielle dans la structure de la distribution des différentes espèces de pouvoir (ou de capital) [...] qui sont en jeu dans le champ, et [...] par leurs relations objectives aux autres positions (domination, subordination, hégémonie, etc.)" ; Pierre Bourdieu and Loïc J.D. Wacquant, Réponses : pour une anthropologie reflexive (Paris : Éditions Du Seuil, 
a triadic relational nexus ${ }^{16}$. Furthermore, by virtue of their field nature, these nationalisms are not internally homogeneous; rather, they are each composed of several competing positions, vying for discursive hegemony within their given field ${ }^{17}$.

I submit the following figure, as a visual representation of Brubaker's triadic nexus of interlocking nationalistic political fields:

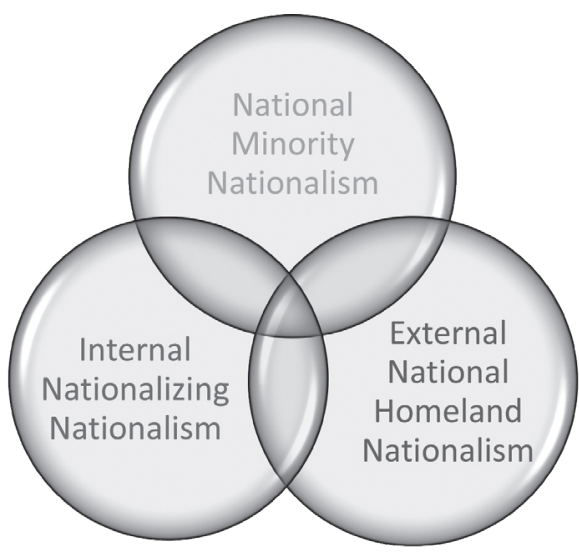

Fig. 1. Rogers Brubaker's triadic relational nexus of nationalistic political fields

Brubaker famously applied his analytical model to several case studies. He used the triadic scheme to explain the restlessness of Russian minority communities in Post-Soviet East-European states. He also applied the scheme in an analysis of the nationalizing policies implemented by the governments of interwar Poland. Most interestingly (from the perspective of our research), he used the triadic model to explain the outbreak of the Serbo-Croatian War of 1991-199518.

In this latter study, Brubaker regards the Serbo-Croatian crisis as the outcome of a succession of contingent events resulting from the interaction and mutual monitoring manifest among a Croatian nationalizing nationalism, a Serbian homeland nationalism, and the minority nationalism of the Serbian diaspora in Croatia. Though emphasizing the importance of event contingency in the outbreak of Serbo-Croatian hostilities, Brubaker is also mindful of the fact that such violent outbreaks have deep roots in the historical memory of Balkan communities; roots which go back to the turmoil of $19^{\text {th }}$ century South-Eastern Europe - the so-called "powder-keg of Europe".

It is this reference to the troubled $19^{\text {th }}$ century history of the Balkans which has inspired me to apply Brubaker's analytical scheme to the interplay of nationalisms underpinning the Macedonian Question.

1992), 72-73 ; on political fields specifically, see Pierre Bourdieu, Propos sur le champ politique (Lyon : Presses Universitaires de Lyon, 2000).

${ }^{16}$ On Brubaker's triadic nexus, see Brubaker, Nationalism Reframed, 58, 67-69.

17 Ibid., 8.

${ }^{18}$ For Brubakers' account of the escalation to (and outbreak of) the Serbo-Croatian war, see Ibid., 69-76. 
However, such an endeavour first requires that Brubaker's analytical model be adjusted to account for the peculiar political circumstances of late $19^{\text {th }}$ century Macedonia:

Firstly, the "battle-lines" of the Macedonian Question are complex and not easily discernible. The issue, presented in nuce, boils down to the following relational configuration: Serbian and Bulgarian nationalism, fighting for the hearts and minds of the Macedonian Slavs; Greek nationalism, opposing both Serbian and Bulgarian nationalisms, in a struggle to win over the very same Slavic Macedonian population; to further complicate things, Romanian nationalism rises in contestation of the Greek nationalism's claim to the Vlach (or Aromanian) inhabitants of Macedonia.

Secondly, all of the aforementioned nationalisms (Bulgarian, Greek, Serbian, and Romanian) acted as nationalizing nationalisms, trying to acculturate the Macedonian population through national schooling and national propaganda. All the while, they presented themselves in the positive light of righteous homeland nationalisms, arisen in defence of their alleged Macedonian diaspora - a diaspora being allegedly "denationalized" by their rival nationalizing nationalisms, which were duly portrayed as aggressive and "evil".

Simply put, the Macedonian population was subject to the action of several nationalizing nationalisms, draped in the ideological disguise of homeland nationalisms. The targeted Macedonian populace, while devoid of any prior national identification, was pushed into choosing a national affiliation. A choice that actually amounted to politically constructing itself as a Greek, Bulgarian, Serbian or Romanian external national minority.

Thirdly, this entire interlocking struggle of competing nationalisms took place on what is still Ottoman territory. While it seems nigh inconceivable for a nation-state to implement nationalizing policies on the territory of another sovereign state, that is precisely what was happening : several nation-states deployed not internal, but external nationalizing nationalisms (building and running schools, publishing propaganda, endorsing national church hierarchies, etc.), in Ottoman Macedonia. This was possible for two reasons. Firstly, the Ottoman state was, by the $19^{\text {th }}$ century, too weakened to squarely oppose foreign intervention into its affairs. And secondly, the Ottoman Empire was not a nation-state. The fact that it operated on non-national principles afforded it a great deal of flexibility in dealing with the national claims of its neighbours: the Ottoman government was, in fact, able to seamlessly incorporate substantial national concessions into its traditional millet system, without outright loss of all internal credibility and international standing. The Ottoman Empire added a supplementary "wild-card" factor to Brubaker's scheme, because the Ottomans sometimes acted in support of one nationalism, and sometimes in support of another, following the fluctuations of their momentary interests within the ebb en flow of Balkan diplomatic contexts. 
Allowing for all these peculiarities which amount to a very complex field structure of numerous interlocked, mutually-monitoring nationalisms, the application of Brubaker's model to $19^{\text {th }}$ century Ottoman Macedonia yields the following figure:

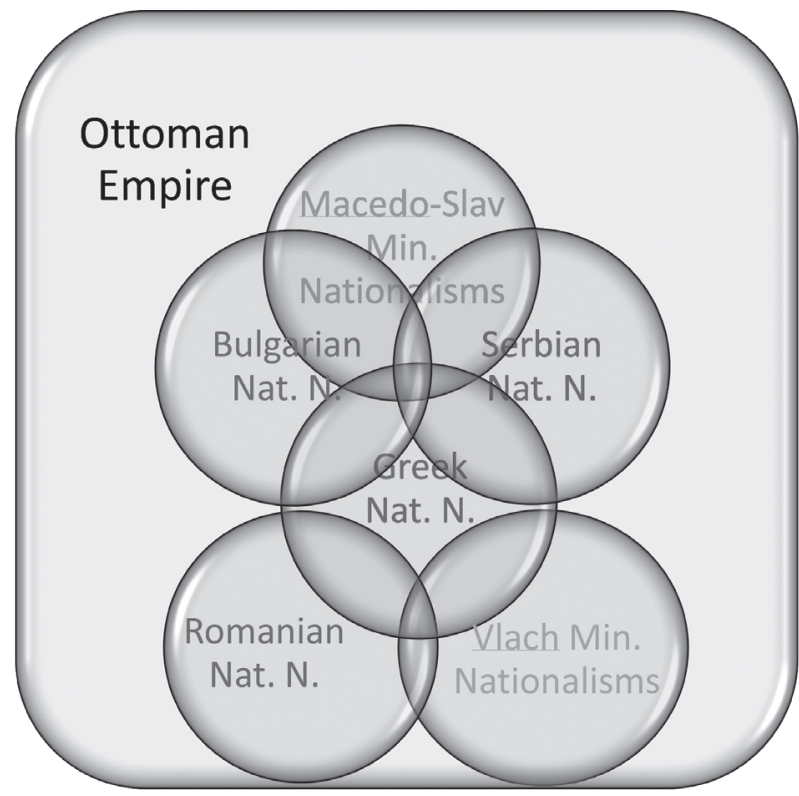

Fig. 2. Rogers Brubaker's analytical model, applied to the 'Macedonian Question'

\section{BRUBAKER'S MODEL, APPLIED TO ANALYZING THE BIRTH OF THE AROMANIAN-ROMANIAN MOVEMENT}

In the previous chapter, I have set out the general frame for the application of Brubaker's model to the analysis of the Macedonian Question. It is now time to showcase its practical implementation in an actual case-study: namely, I shall be analysing the birth of the Aromanian-Romanian ${ }^{19}$ national movement (or the "Aromanian Question'), from the perspective of its being influenced by the triadic interaction among

${ }^{19}$ We borrow the designation of this movement as 'Aromanian-Romanian' from Thede Kahl - see Thede Kahl, Istoria aromânilor: vlahi şi meglenoromâni din Europa de Sud-Est [The History of the Aromanians: Vlachs and Meglenoromanians from South-Eastern Europe] (Bucureşti: Editura Tritonic, 2005), 32. In choosing the designation 'Aromanian-Romanian', Kahl takes into account the specificities of this national movement: the most active participants of the movement are Aromanians from Macedonia, and not Romanians. However, the movement could not have gotten under way and developed without massive Romanian state backing. As such, we have chosen to adopt Kahl's terminology, as being most appropriate for describing the Romanians' and Aromanians' joint efforts in Macedonia. 
a Romanian external nationalizing nationalism, a Greek external nationalizing nationalism (both being deployed in Ottoman Macedonia), and two Aromanian minority nationalisms (one pro-Greek, one pro-Romanian). As shown in the following figure:

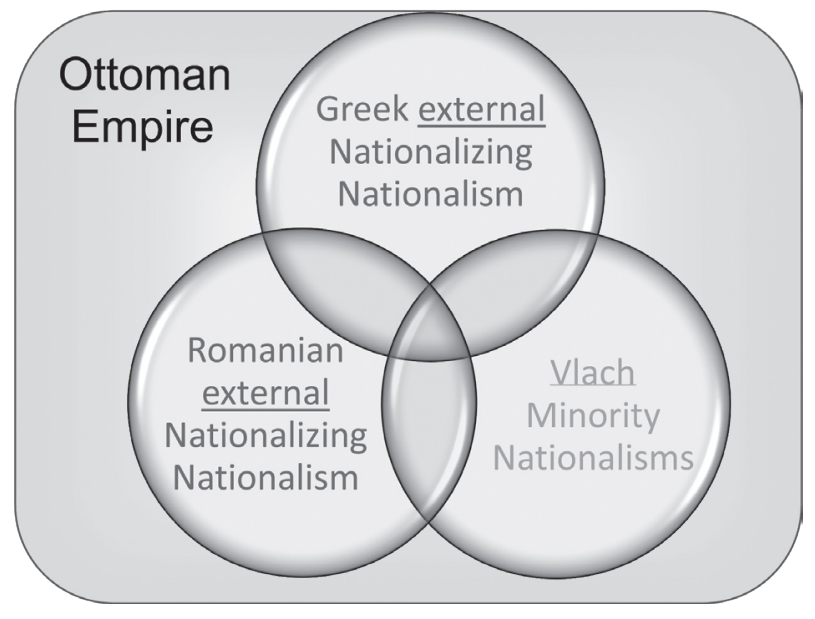

Fig. 3. Brubaker's analytical model, applied to the so-called 'Aromanian Question'

At the turn of the $20^{\text {th }}$ century, the Aromanians - also known throughout the Balkans as Vlachs, Koutzovlachs or Tzintzars ${ }^{20}$ - were a population of shepherds, merchants and caravan drivers spread out all throughout the Balkans, in isolated mountain communities. They spoke a romance language (A dialect of Romanian ${ }^{21}$ ), and were, most likely, the descendants of Roman legionaries and colonists that had been settled in the region.

Having been heavily Hellenized ever since the $18^{\text {th }}$ century (if not earlier) ${ }^{22}$, this population had taken an active part in the Greek struggle for national independence, and was duly viewed, in Greek circles, as legitimately Hellenic.

In the latter half of the $19^{\text {th }}$ century however, the Romanian government began to take an interest in the Aromanians. Romanian primary and secondary schools were founded all over Macedonia, as well as high-schools and commercial schools in Salonica, Bitolia, Iannina and Berati ${ }^{23}$. Efforts were equally deployed to secure the

20 These being only the most prominent among a host of ethnonyms and nicknames used by the various Balkan peoples, to designate the Vlachs; see Nicolas Trifon, Les Aroumains, un people qui s'en va (La Brussière: Editions Acratie, 2005), 10.

21 See Matilda Caragiu Marioțeanu, "Unité du roumain (nord et sud-danubien)”, Revue roumaine de linguistique XXX, 6 (1985) ; see also Nicolae Saramandu, La Romanité Orientale (Bucureşti : Editura Academiei Române, 2008), 167-178 (Chapter "Les dialectes roumains au nord et au sud du Danube").

22 Peyfuss, "Aromânii în era naționalismelor balcanice" ["The Aromanians in the Era of Balkan Nationalisms"], 177.

${ }^{23}$ Ibid., 172-173. 
use of the Romanian language (either literary Romanian or Aromanian dialect) in the religious service ${ }^{24}$.

One of the first activists of the burgeoning Aromanian-Romanian movement (if not, arguably, its founder) was Dimitrie Cazacovici, from the prosperous Aromanian town of Metzovo (arom. Aminciu), in the Pindus Mountains. Cazacovici left his home at an early age, to join his Uncle Petre Cazacovici's lucrative business, in Budapest. This is where he met Mihail Boiagi ${ }^{25}$, and thus came into contact with the Aromanian movement in Austro-Hungary ${ }^{26}$. Fired up by national pride, he subsequently decided to go to Wallachia, where he joined Ion Câmpineanu's National Party ${ }^{27}$, and in 1834 became an officer in the Wallachian army ${ }^{28}$.

The union of the two Romanian Principalities (Wallachia and Moldavia), in January of 1859, represented a partial accomplishment of the Romanian national idea. This achievement bolstered the confidence of Romania's intellectual leadership (composed largely of former 1848 revolutionaries), inspiring it to direct its gaze towards the so-called 'Romanians of the Balkans'29. Cazacovici seized upon this opportunity, and published a series of articles in the "Dâmbovița" periodical - a journal founded in October 1858 by the former 1848 revolutionary Dimitrie Bolintineanu ${ }^{30}$. Cazacovici's articles aimed to acquaint the Romanian public with the particulars of Aromanian history, and of the Aromanian dialect ${ }^{31}$. In 1859, Cazacovici published a summons addressed to the Aromanians living in the Romanian Principalities, calling them to gath-

24 Ibid., 174-175.

25 Max Demeter Peyfuss, Chestiunea aromânească : evoluția ei de la origini până la Pacea de la Bucureşti (1913) şi poziția Austro-Ungariei [The Aromanian Question: its Evolution from its Origins to the Peace of Bucharest (1913) and the Stance of Austro-Hungary] (Bucureşti: Editura Enciclopedică, 1994), 35.

${ }^{26}$ During the $19^{\text {th }}$ century, Budapest and Vienna become a gathering place for an Aromanian diaspora - including some Aromanians who had sought refuge from the destruction of the township of Moschopolis, where, in the $18^{\text {th }}$ century, Aromanian culture had experienced its first bloom (albeit in the Greek language, and under the sway of Hellenic culture). These Aromanian expatriates came into contact with the Romanian national movement in Transylvania (Andrei Şaguna, Inochentie Micu, Gheorghe Şincai, Petru Maior), and, partially under the influence of the Transylvanian movement, started publishing in Aromanian, thus cultivating their native language and culture. The Aromanian diaspora in AustroHungary produced such figures as Constantin Ucuta, Gheorghe Constantin Roja and Mihail Bioagi; see Valeriu Papahagi, Moscopole: Metropola comercială şi culturală a românilor din Peninsula Balcanică in secolul al XVIII-lea [Moschopolis: The Commercial and Cultural Metropole of the Romanians of the Balkan Peninsula in the XVIIIth Century] (Roşiorii de Vede: Tipografia "Lumina Poporului", 1939), 14-15; Peyfuss, Chestiunea Aromânească [The Aromanian Question], 24-30.

27 Sterie Diamandi, Oameni şi aspecte din istoria aromânilor [People and Aspects of Aromanian History] (Bucureşti: 1940), 275.

28 Peyfuss, Chestiunea Aromânească [The Aromanian Question], 35; Diamandi, Oameni şi aspecte [People and Aspects], 275-276.

29 Peyfuss, Chestiunea Aromânească [The Aromanian Question], 35.

30 Ibid., 34.

31 Diamandi, Oameni şi aspecte [People and Aspects], 277-278. 
er funds for the setting up of Romanian schools in the Balkans ${ }^{32}$. One year later, in 1860, Cazacovici managed to establish in Bucharest a Macedo-Romanian Committee. This organization attracted two types of adherents: on the one hand, pro-Romanian Aromanian activists, and on the other, high-profile members of Romania's political and intellectual elite. As such, the establishment of this Committee may be regarded as the "birth certificate" of Romanian nationalizing nationalism in the Balkans: the Macedo-Romanian Committee was, in effect, the institutional core of a political field which immediately started exerting its nationalizing influence in Macedonia. In 1860 , the first order of business for the freshly-founded committee was the publication of a call to action directed towards the Aromanians of European Turkey ${ }^{33}$. A further manifesto was published in 1863, in both Aromanian and Greek, and distributed throughout Turkey.

The Committee's manifestoes soon bore fruit: Dimitrie Atanasescu, a 25-year-old Aromanian tailor from Trnovo, entered an Istanbul coffee shop only to stumble upon the Committee's 1860 proclamation to the Aromanians of Turkey ${ }^{34}$. The proclamation spurred him into action. Atanasescu arrived in Bucharest on July $20^{\text {th }} 1861^{35}$, having resolved to study here, and return to his native township as a Romanian teacher. Three years later, having not even finished his studies, Atanasescu wrote to A.I. Cuza, the then ruler of Romania, asking for financial support for the opening of a Romanian school in Macedonia ${ }^{36}$. Cuza forwarded the petition to Dimitrie Bolintineanu, who was the Minister of Public Instruction (and a prominent member of the Macedo-Romanian Committee!). With Bolintineanu's support, Atanasescu received the requested funds; on July $2^{\text {nd }} 1864$ he proceeded to opening, in his native Trnovo, the first Romanian school south of the Danube ${ }^{37}$. The rival political field of Greek nationalizing nationalism immediately reacted to this stepping up of Romanian nationalizing influence in Macedonia: no sooner had Dimitrie Atanasescu opened his school, than the local Greek ecclesiastical authorities started persecuting him. In November 1864, the Archbishop Benedict of Pelagonia had Atanasescu arrested, and had 1,000 of his Romanian manuals confiscated ${ }^{38}$. Atanasescu was soon released, but in 1865 had to flee back to Romania.

The Romanian nationalizing political field responded to Greek pressure by creating an official, state-funded institution for the training of Aromanian schoolteach-

\footnotetext{
32 Vasile Muşi, "Românii din dreapta Dunării şi Unirea din 1859" ["The Romanians from the RightHand Side of the Danube and the 1859 Union"], Destin [Destiny] 11 (1959) : 223.

33 Peyfuss, Chestiunea Aromânească [The Aromanian Question], 35. Sadly, the text of the proclamation has not been preserved.

34 Diamandi, Oameni şi aspecte [People and Aspects], 288.

35 Ibid., 290.

36 For the full text of Atanasescu's petition, see Victor Papacostea, "Documente aromâneşti dintre 1860 şi 1870" [“Aromanian Documents from 1860 to 1870”], Revista Aromânească [Aromanian Review] 1, 2 (1929): 170-171.

37 Diamandi, Oameni şi aspecte [People and Aspects], 293.

38 Peyfuss, Chestiunea Aromânească [The Aromanian Question], 38.
} 
ers - educators meant to staff a prospective network of Romanian schools, to be established south of the Danube.

Consequently, on July $28^{\text {th }} 1865$ the Ministry of Public Instruction allocated 20,000 lei from the State budget towards the establishment of a Bucharest boarding school for Aromanian children, to be trained as teachers for the future Romanian schools in Macedonia; 14,000 lei was granted to the monk Averchie, who was thus contracted to travel to his homeland in the Pindus mountains and return with 10 boys, 12 to 14 years of age, selected so as to be "as intelligent as possible, and literate". One of Bucharest's monasteries was to provide the rooms for the boys to be lodged in. The total sum of 9,900 lei was allocated for the ten schoolchildren's needs, and Averchie was then charged with the administration of these funds. Each teacher of the establishment was awarded a salary of 4,000 lei, and 2,100 lei was put aside for unforeseen expenses ${ }^{39}$.

Averchie lived up to his end of the bargain, returning to Bucharest in the autumn of 1865, with 10 Aromanian boys from the townships of Abdella (arom. "Abela" or "Avdela"), Kato Bermion (arom. Selia) and Peribolion (arom. Perivoli) ${ }^{40}$. The monastery of "The Saint Apostles" (rom. "Sfinții Apostoli") was selected as the location of the boarding house.

The Romanian nationalizing field further responded to the Greek persecution of its agents by lobbying the Ottoman Sultan to pass legislation protecting the AromanianRomanian movement's activists in Macedonia. This Romanian lobby soon bore fruit: the August 30 ${ }^{\text {th }} /$ September $12^{\text {th }} 1878$ decree of the Grand Vizier Savfet Pasha brought about the first official recognition of the Aromanians' existence in Macedonia, as a distinct ethnic group ${ }^{41}$. Even though the local Ottoman administration consistently found ways to circumvent the provisions of the 1878 decree $^{42}$, this document represented a great step forward for the Aromanian-Romanian movement - one that anticipated the even greater national triumph of 1905, the Sultan's famous iradé.

In that very same year of 1878 , Bucharest elevated Apostol Margarit to the position of Inspector General of all Romanian schools in the Balkans ${ }^{43}$. This position was conceived especially for Margarit, effectively making him the quasi-absolute leader of the Aromanian-Romanian national movement.

${ }^{39}$ For the full text of the resolution of the Ministry of Public Instruction concerning the Aromanian boarding house, see Victor Papacostea, "Documente aromâneşti dintre 1860 şi 1870" ["Aromanian Documents from 1860 to 1870”], Revista Aromânească [Aromanian Review] 1, 1 (1929): 82-83.

40 Peyfuss, Chestiunea Aromânească [The Aromanian Question], 39; see also Victor Papacostea, "Documente aromâneşti dintre 1860 şi 1870" ["Aromanian Documents from 1860 to 1870"], Revista Aromânească [Aromanian Review] 1, 1 (1929): 84-85.

41 The decree effectively ordered the local administration of the Macedonian vilayets to protect the Aromanian population, specifically regarding their right to an education in their own, native tongue; for the full text of Savfet Pasha's decree, see Diamandi, Oameni şi aspecte [People and Aspects], 335.

42 Peyfuss, Chestiunea Aromânească [The Aromanian Question], 50.

43 S. Țovaru, Problema şcoalei româneşti din Balcani [The Issue of Romanian Schooling in the Balkans] (Bucureşti: 1934), 28. 
Margarit used his new authority to great effect - his appointment as Inspector General ushers in the golden age of the Aromanian-Romanian movement. During Margarit's 24 years in office (1878-1902), 104 Romanian primary schools and 4 secondary schools were opened in Macedonia. By comparison, in the 13 years preceding Apostol's inspectoral mandate (1864-1877), only 9 schools were opened (two of which were founded by Margarit himself), whereas in the decade after his retirement (1903-1912), only 20 new schools were established ${ }^{44}$.

However, Apostol Margarit's very adhesion to the Aromanian-Romanian movement was, in itself, a product of the mutual monitoring and interaction of the Greek and Romanian nationalistic political fields.

After having finished his primary education, the young Apostol was sent away from home, to continue his studies at the Greek secondary school in Janina. This school was a veritable hotbed of Hellenic nationalism ${ }^{45}$ - unsurprisingly, the young Apostol became caught up in the Greek national zeal of this environment, and decided to become a Greek teacher. He started his teaching career in $1856^{46}$ in a small village, but was quickly promoted to a more important township - Kleisoura (arom. 'Clisura', or 'Vlaho-Clisura'). This was an Aromanian settlement, and Apostol Margarit quickly discovered that young Aromanian schoolchildren were having trouble acquiring knowledge which was taught in Greek, rather than in their native Aromanian. Margarit made the necessary adjustment and started using Aromanian in the classroom, in conjunction with Greek ${ }^{47}$. In making this call Margarit unknowingly distanced himself from the Greek nationalizing political field, while at the same time repositioning himself within an emergent minority nationalism of the Macedonian Vlachs (the one which would, in time, become pro-Romanian). This subtle transition immediately prompted a reaction from the Greek nationalizing political field: the Greek Patriarchate tried to get Margarit fired. In response, the Kleisouran villagers expressed their support for the much-loved educator ${ }^{48}$ - this being the Aromanian minority nationalism's response to Greek pressure. Margarit himself reacted by going to Constantinople were he obtained an official Ottoman sanction to open a private school in Kleisoura ${ }^{49}$, which entailed official protection from the Patriarchate's persecution $^{50}$. In the meantime, Margarit had also gone to Bucharest on a local Kleisoura administrative errand. There he had come into contact with the Macedo-Romanian Committee, and thus had joined the Aromanian-Romanian national movement. On May $11^{\text {th }} / 24^{\text {th }} 1866$ Margarit petitioned the Romanian Minister of Public Instruction,

44 See Ibid., passim;

45 Diamandi, Oameni şi aspecte [People and Aspects], 325.

${ }^{46}$ Mihail Pinetta, Apostol Margarit (Iaşi: 1940), 39.

47 Peyfuss, Chestiunea Aromânească [The Aromanian Question], 42.

${ }^{48}$ See the Patriarchy's order towards the Clisura leadership, demanding Margarit's sacking, and the Clisura locals' reply, reproduced in Diamandi, Oameni şi aspecte [People and Aspects], 330-331.

49 Ibid., 332.

${ }^{50}$ Peyfuss, Chestiunea Aromânească [The Aromanian Question], 42. 
asking for funds for opening a Romanian school in Macedonia ${ }^{51}$. Having received the requested funds, he proceeded to opening a school in his native village of Abdella ${ }^{52}$. Thus, Margarit joined the Romanian nationalizing political field - and the national movement that it was on the verge of engendering. The rest, as they say, is history.

In conjunction with his role in the development of the Romanian school network, Margarit was also heavily involved in efforts to achieve Aromanian religious autonomy in Macedonia. In effect, Romania's goal was the establishment of an autocephalous Aromanian bishopric in the region, the main stake of the matter being the right to use Aromanian (instead of Greek) in the religious service. However, the project was soon blocked by the Greek Patriarchate: the Sultan never issued the Aromanian bishop's official berat of investiture. In 1901, disenchanted with the lack of progress in the question of the bishopric, Antim - the prospective bishop hand-picked by Margarit himself - abandoned the Romanian movement ${ }^{53}$.

Furthermore, Apostol Margarit's multipronged efforts in advancing the Romanian cause soon drew the ire of the rival, philo-Greek Aromanian minority nationalism: during his mandate as inspector of the Romanian schools, Margarit survived two assassination attempts. In 1881, he escaped the daggers of Pindu Tuşica and T. Modi by playing dead. The second attempt on his life was made in Thessaloniki, in 1890 . This time, the assassin came very close to succeeding: Apostol Margarit was seriously wounded ${ }^{54}$.

Nor does Margarit's success go unnoticed by his enemies within the AromanianRomanian movement. Brubaker emphasizes the fact that nationalisms, being political fields, are not homogeneous, often harbouring multiple competing positions ${ }^{55}$; the Romanian nationalizing nationalism in Macedonia was no different: Margarit's first conflict with his rivals inside the field came in April of 1883, when several teachers of the Monastir secondary school, led by the school's headmaster, I. GheorghiadeMurnu, left the establishment to form their own separate school in Monastir ${ }^{56}$; this establishment was short-lived. However, new tensions surfaced in 1890 and 1891. This time, eighteen teachers of the Monastir secondary school took their complaints against the Inspector General to Bucharest. The dissenters were openly supported by Spiru Constantinescu, the Romanian consul in Monastir. By 1894, with the consul's support, they succeed in creating a second school administration system, with its own

${ }^{51} \mathrm{Ibid} ., 42$.

52 Ibid., 42; the school in Abdella functioned yearly, only during summer (since in the winter, virtually the entire population of the village migrated to the sheep herds' winter quarters, on the Thessaly plain), until the Greek attack and the torching of the village, in 1905.

${ }^{53}$ Peyfuss, Chestiunea Aromânească [The Aromanian Question], 70.

${ }^{54}$ Diamandi, Oameni şi aspecte [People and Aspects], 342.

55 "[...] the three "elements" in the triadic relation are themselves not fixed entities but fields of differentiated and competing positions, arenas of struggle among competing stances."; Brubaker, Nationalism Reframed, 8.

${ }^{56}$ Peyfuss, Chestiunea Aromânească [The Aromanian Question], 72. 
Romanian schools and teachers ${ }^{57}$. This system was, obviously, in direct competition with the one run by Margarit.

It was soon revealed that several influential members the Romania's Conservative Party had long been trying to get Margarit fired ${ }^{58}$. Momentarily however, the favour of King Carol I and that of Liberal Party leader D.A. Sturdza had allowed Margarit to stay in office in spite of these hostile plots.

The mounting tension between the Greek and Romanian nationalizing fields soon "spilled over" into the realm of diplomacy, embittering Romanian-Greek bilateral relations: given Romania's intensifying national propaganda in Macedonia, the 1879 opening of a Romanian consulate in Thessaloniki aggravated Greek public opinion and led even King George I to express his displeasure ${ }^{59}$. The Romanian consul proceeded to further fan the flames of Greek discontent, by declaring that there were no Greeks whatsoever in Thessaloniki ${ }^{60}$.

In this climate of mutual apprehension the two nationalizing fields clashed again, with the signing of the 1881 Constantinople convention. This act put into effect an earlier decision of the Great Powers - one drawn up during the 1878 Berlin Congress, and pertaining to the northern expansion of Greek national territory to include Thessaly and the Arta region of Epirus. This measure stood for an effective enhancement of the Greek state by $13.800 \mathrm{~km}^{2}$ and almost 293,000 inhabitants ${ }^{61}$, for the most part Greeks. However, large Aromanian communities also lived in the region, and the new proposed northern border of Greece effectively separated the Aromanian shepherd communities of the Pindus and Gramos mountains from their winter herding grounds in the plains of Thessaly and on the Ionian Sea coast ${ }^{62}$.

The retort of the Romanian nationalizing field was prompt: Apostol Margarit, together with I. Caragiani and several other Romanian teachers of the area, proceeded to draft a memorandum ${ }^{63}$ opposing the cession of the aforementioned territories to Greece. This petition, the text of which has been lost, was presented to the delegates of the Constantinople conference on May $26^{\text {th }} /$ June $8^{\text {th }} 1881^{64}$. Its grievances were ignored. Later on the representatives of the Great Powers were presented with a further petition, signed by six delegates of the Aromanian population of Macedonia, Epirus

${ }^{57}$ Ibid., 73-74.

58 Ibid., 74.

59 Ibid., 55.

${ }^{60} \mathrm{Ibid} ., 56$.

${ }^{61}$ Constantin Velichi, "Les relations roumano-grecques pendant la période 1879-1911", Revue des Etudes Sud-Est Européennes 7, 3 (1969) : 515.

${ }^{62}$ See Apostol Margarit, Refutation d'une brochure grecque par un Valaque Epirote, extracted from Courrier d'Orient (Constantinople : 1879), 30.

${ }^{63}$ According to Jeanne Z. Stephanopoli, Trente deux ans de propagande roumaine en Macédoine. Les Koutzovlaques et l'Hellénisme (Athens: 1903), 14-17, the said memorandum will have been drafted by the Romanian embassy in Constantinople.

${ }^{64}$ Peyfuss, Chestiunea Aromânească [The Aromanian Question], 57. 
and Thessaly ${ }^{65}$. The signatories argued that the Aromanians were "an element of order and stability in the Balkans" 66 , and as such, their wishes should not be ignored. This second plea also fell on deaf ears. The new Greek border was finally fixed on the River Arachthos and River Peneios ${ }^{67}$, effectively splitting the dense, homogeneous Aromanian population of the Pindus mountains in half.

Though Romania officially supported Greece's annexation of Thessaly and the Arta region ${ }^{68}$, the new Greek border was effectively dismantling the territorial basis for Romania's plans to create an autonomous Aromanian region in Albania ${ }^{69}$. This fact negatively impacted Romano-Greek relations in the long run.

A belated attempt was made to smooth over the mounting bilateral discord, via a meeting of monarchs: Carol I of Romania and George I of Greece convened at the hot-springs resort of Abazzia, in the spring of $1901^{70}$. During this informal meeting Carol reportedly tried to allay George's apprehensions regarding Romanian propaganda in Macedonia, while the Greek monarch promised support for the Aromanians in their struggle for ecclesiastical autonomy ${ }^{71}$. However, beyond this mutual exchange of promises and pleasantries Abazzia brought no tangible solutions to the tensions between the two countries.

But what of the Aromanian minority nationalisms? As we have seen, the Macedonian Aromanians were being claimed by two competing national discourses - one hailing from Bucharest, the other from Athens; therefore, each individual was faced with a choice: dividing lines of national allegiance were soon drawn. That is to say that, in fact, the emerging Aromanian minority political field was soon torn in half by the interaction of Romanian and Greek nationalizing political fields.

On the one side, there were the so-called 'romanophiles', who saw in forging cultural ties with Romania the natural path to strengthening and developing their own culture. They therefore accepted the support and leadership of Bucharest, and welcomed Romanian involvement in the Macedonian question. The Kleisouran villagers' early

65 Ibid., 57.

66 Stelian Brezeanu, Constantin Iordan, Horia C. Matei, Tudor Teoteoi, Gheorghe Zbuchea, Relațiile româno-elene: o istorie cronologică [Romanian-Hellene Relations: a Chronological History] (Bucureşti: Editura Omonia, 2003), 212.

67 Peyfuss, Chestiunea Aromânească [The Aromanian Question], 57.

68 See Stelian Brezeanu et al., Relațiile româno-elene [Romanian-Hellene Relations], 212.

69 Peyfuss, Chestiunea Aromânească [The Aromanian Question], 57; on the various Romanian plans for Aromanian autonomy in the Balkans, see Marius Diaconescu, "Some Critical Remarks on the Role of Romania in the Balkan Wars" (paper presented at the annual global conference of the United Macedonian Diaspora, Skopje, Macedonia, July 24 - August 2, 2013, to be published).

70 See Stelian Brezeanu et al., Relațiile româno-elene [Romanian-Hellene Relations], 218 ; Radu Tudorancea, "The Macedo-Romanian Question Within Romanian-Greek Relations in the Early Twentieth Century (1900-1913)", in Historical Yearbook (Bucharest: Romanian Academy, "Nicolae Iorga" History Institute, Volume I, 2004), 214.

71 Michel Lhéritier, L'évolution des rapports gréco-roumains depuis un siècle (1821-1931) (Paris : 1933), 585. 
defence of Margarit's teaching policies is an example of this minority nationalism's taking action. On the opposite side, there were the 'grecomani' who, though still holding themselves to be Aromanian, believed that breaking their traditional allegiance to Hellenic culture would be a mistake, and the stem of unnecessary conflict with the Greek population. They therefore chose to support the Greek cause ${ }^{72}$. The two attempts on Margarit's life, performed in 1881 and 1890 by grecoman Aromanians, are instances of the pro-Greek minority nationalism manifesting itself.

The brewing conflict took a violent turn when the Greek government started sending armed bands of Antartes (rebels) across the Greco-Macedonian border: a strong offensive on the part of the Greek nationalizing political field. These bands started harassing pro-Romanian Aromanian communities. The outbreak of the Ilinden rebellion, on the July $20^{\text {th }} /$ August $2^{\text {nd }} 1903$ (on Saint Elijah's day), fanned the flames of Aromano-Greek violence.

The Greek antartes often tried to bully whole communities into renouncing their pro-Romanian beliefs and closing down their Romanian schools. It was hinted that non-compliance would be met with deadly force ${ }^{73}$. More than once, such threats were carried out ${ }^{74}$.

Even so, many Romanophiles chose to stand by Romania's official ruling (the King of Romania had urged Aromanians not to take up arms ${ }^{75}$ ). Some, however, resolved to go against Bucharest's wishes, rise in defence of their kin, and pay the Greek aggressor in kind.

In other words, while most Aromanians sided with the official stance of Romanian nationalizing nationalism, refusing to fight the Greeks, some chose to embrace a distinct path - one belonging to the Aromanian minority nationalism: the path of armed resistance.

Guerrilla warfare broke out between the bands of pro-Romanian Aromanian Armatoles (weapon bearers) on one side, and the Greek Antartes (rebels), aided by grecoman Aromanians, on the other. This insidious violent struggle lasted up to the conclusion of the Second Balkan War, in 1913.

As for Roumano-Greek diplomatic tensions, they reached their climax on May $10^{\text {th }} / 22^{\text {nd }} 1905$, when an Ottoman iradé officially acknowledged the existence of a separate Aromanian nation in Turkey, therefore granting Aromanians the same rights and privileges enjoyed by all the other legitimately recognized ethno-national com-

72 Ionuț Nistor, "Problema aromână” în raporturile României cu statele balcanice (1903-1913) [The "Aromanian Issue" in Romania's Rapports with the Balkan States (1903-1913)] (Iaşi : Editura Universității "Alexandru Ioan Cuza”, 2009), 26.

73 See Trifon, Les Aroumains: un people qui s'en va, 218.

74 For instance, in 1905, the Aromanian village of Avdella was burned to the ground, and its pro-Romanian notables were executed.

75 Peyfuss, "Aromânii în era naționalismelor balcanice" ["The Aromanians in the Era of Balkan Nationalisms"], 180; Trifon, Les Aroumains: un people qui s'en va, 218. 
munities in the Empire. Namely, "their (the Aromanians' - n.a.) communities are allowed to elect muhtari (mayors - n.a.), in agreement with the laws in force, such as done on a customary basis by the other communities; the Vlachs should also be accepted in the administration councils, the Imperial authorities should enable the appointed teachers of these communities to inspect their schools, and allow the fulfilment of all the formalities required by the laws of the Empire so as to open new schools."76 Additionally, the Ottoman Minister of Justice and Cults sent a teşkeré to the Greek Patriarch Joachimos III, instructing the latter that "the Vlachs shall not be prevented from having their cultic ceremonies celebrated by their own priests and in the national language, nor shall they be prevented from using this language in their schools."77

Unsurprisingly, the Greek nationalizing nationalist political field met this recognition of Vlach national rights with great hostility: the Greek terrorist bands in Macedonia redoubled their persecutions of Aromanian communities ${ }^{78}$, and Greece broke diplomatic relations with Romania ${ }^{79}$, for the second time in a little over a decade $^{80}$. Diplomatic relations were only resumed on March $24^{\text {th }} /$ April $5^{\text {th }} 1911$, on the eve of the First Balkan War ${ }^{81}$.

In the end however, Greek hostility could do nothing to mitigate the significance of the 1905 iradé: this official acknowledgement of the Aromanian 'nation' constituted the Romanian nationalizing nationalism's brightest hour - the peak achievement of the Aromanian-Romanian national movement.

76 Excerpt from the iradé of the Sultan dated 17 Rebiülevvel/ 22 $2^{\text {nd }}$ of May 1905, taken from Tudorancea, “The Macedo-Romanian Question Within Romanian-Greek Relations”, 215;

77 Excerpt from Minister Abbduraahman's aforementioned teşkeré, taken from Gheorghe Zbuchea, O istorie a românilor din Peninsula Balcanică (secolele XVIII-XX) [A History of the Romanians of the Balkan Peninsula (XVIIIth - XIXth Centuries)] (Bucureşti: Ed. Biblioteca Bucureştilor, 1999), 73.

${ }^{78}$ For an eye-witness, participant's account of the struggle between Geek and Aromanian partisan bands, in and around 1905, see Cola Nicea, "Memorii" ["Memoirs"], in Scara - revistă de oceanografie ortodoxă [The Ladder - Review of Orthodox Oceanography] (Bucharest: Ed. Treapta 7, 2001), digitalized by Predania Publishing House, accessed and downloaded May 23, 2013, from http://www.proiectavdhela.ro/pdf/cola_nicea_memoriile.pdf.

${ }^{79}$ See Stelian Brezeanu et al., Relațile româno-elene [Romanian-Hellene Relations], 219-220 ; Tudorancea, "The Macedo-Romanian Question Within Romanian-Greek Relations", 215-216.

${ }^{80}$ Romano-Greek diplomatic relations had also been interrupted between September $20^{\text {th }} /$ October $3^{\text {rd }} 1892$ and July 19 $19^{\text {th }} 31^{\text {st }} 1896$; on those occasions, Greece had called back its ambassador and consuls on account of the so-called 'Zappa affair' - a disagreement over the inheritance left behind by a very wealthy businessman of both Romania and Greek citizenship, named Evanghelie Zappa; on the particulars of the Zappa affair and ensuing break of diplomatic relations, see Georges Streit, L'affaire Zappa. Conflit greco-roumain (Paris: 1894) ; for the 'reader's digest' version, see Stelian Brezeanu et al., Relațiile româno-elene [Romanian-Hellene Relations], 215-216.

${ }^{81}$ For a detailed account of the entire 1905-1911 Greco-Romanian diplomatic crisis, see Velichi, "Les relations roumano-grecques pendant la période 1879-1911”, 535-542. 
Unfortunately, this victory would prove to be short-lived. The two Balkan Wars (1912-1913), and the ensuing peace treaties of London (May 1913) and Bucharest (August 1913), put an end to Ottoman domination in South-Eastern Europe. Macedonia was divided between Serbia, Bulgaria and Greece - which effectively rendered the 1905 iradé null and void. The Bucharest peace treaty should have afforded Romania an opportunity to negotiate some sort of protected status for the Macedonian Aromanians. Sadly, Romania's actions in this respect proved insufficient: though the Romanian government attempted to secure Aromanian cultural privileges via the exchange of official diplomatic notes with the other Balkan governments, this ultimately achieved little in the long run. Since the aforementioned diplomatic notes held no standing in international law, the fact that the Aromanians were never mentioned in the text of the peace treaty itself ${ }^{82}$ ultimately left their communities vulnerable to Serbian, Bulgarian, and Greek cultural assimilation.

The future of Aromanian communities in the Balkans proved to be bleak indeed.

\section{FINAL THOUGHTS}

The purpose of this paper has been to showcase the potential application of Brubaker's triadic model of interaction among nationalistic political fields; more specifically, in a case study of the birth and early development of the AromanianRomanian national movement.

One point should be made perfectly clear however: the present work is but an ébauche, warranting much further development. In fact, Brubaker's analytical scheme allows for so much variety and flexibility, that pursuing the analysis down to the level of the smallest circumstantial event and detail is liable to add layers and layers of depth - not only to our understanding of the Aromanian-Romanian movement, but to any study of triadically interacting nationalisms.

Highlighting the merits of such an approach was the ultimate goal of the present paper.

82 See Peyfuss, "Aromânii în era naționalismelor balcanice" ["The Aromanians in the Era of Balkan Nationalisms"], 181. 


\section{BIBLIOGRAPHY}

BARTH, Fredrik, ed., Ethnic Groups and Boundaries : The Social Organization of Culture Difference (London: Allen \& Unwin, 1969)

BOURDIEU, Pierre, Propos sur le champ politique (Lyon : Presses Universitaires de Lyon, 2000)

BOURDIEU, Pierre and Wacquant, Loïc J.D., Réponses: pour une anthropologie réflexive (Paris: Ed. Du Seuil, 1992)

BRASS, Paul, Ethnicity and Nationalism, Theory and Comparison (New Dehli: Sage Publications, 1991)

BREZEANU, Stelian, Constantin Iordan, Horia C. Matei, Tudor Teoteoi, Gheorghe Zbuchea, Relațiile româno-elene: o istorie cronologică [Romanian-Hellene Relations: a Chronological History] (Bucureşti: Editura Omonia, 2003)

BRUBAKER, Rogers, Nationalism Reframed: Nationhood and the National Question in the New Europe (Cambridge: Cambridge University Press 1996)

CARAGIU-MARIOȚEANU, Matilda, "Unité du roumain (nord et sud-danubien)", in Revue roumaine de linguistique, XXX, 6 (1985)

CASTELLAN, Georges, Histoire des Balkans XIVe-Xxe siècle (Fayard, 1991)

DIACONESCU, Marius, "Some Critical Remarks on the Role of Romania in the Balkan Wars" (paper presented at the annual global conference of the United Macedonian Diaspora, Skopje, Macedonia, July 24 - August 2, 2013, to be published)

DIAMANDI, Sterie, Oameni şi aspecte din istoria aromânilor [People and Aspects of Aromanian History] (Bucureşti: 1940)

HOBSBAWM, Eric, Nations et nationalisme depuis 1780, trans. Dominique Peters (Paris: Gallimard, 1992)

JELAVICH, Barbara, Istoria Balcanilor [History of the Balkans], vol. II (Iaşi: Institutul European, 2000)

KAHL, Thede, Istoria aromânilor: vlahi şi meglenoromâni din Europa de Sud-Est [The History of the Aromanians: Vlachs and Meglenoromanians from South-Eastern Europe] (Bucureşti: Editura Tritonic, 2005)

LHÉRITIER, Michel, L'évolution des rapports gréco-roumains depuis un siècle (1821-1931) (Paris: 1933)

MARGARIT, Apostol, Refutation d'une brochure grecque par un Valaque Epirote, extracted from Courrier d'Orient (Constantinople: 1879)

MUŞI, Vasile, "Românii din dreapta Dunării şi Unirea din 1859" ["The Romanians from the Right-Hand Side of the Danube and the 1859 Union"] in Destin [Destiny] 11 (1959)

NICEA, Cola, "Memorii” ["Memoirs"], in Scara - revistă de oceanografie ortodoxă [The Ladder-Review of Orthodox Oceanography] (Bucharest: Ed. Treapta 7, 2001), digitalized by Predania Publishing House, accessed and downloaded May 23, 2013, from http://www.proiectavdhela.ro/pdf/cola_nicea memoriile.pdf.

NISTOR, Ionuț, "Problema aromână” în raporturile României cu statele balcanice (1903-1913) [The "Aromanian Issue" in Romania's Rapports with the Balkan States (1903-1913)] (Iaşi: Editura Universității "Alexandru Ioan Cuza", 2009)

PAPACOSTEA, Victor, "Documente aromâneşti dintre 1860 şi 1870" [“Aromanian Documents from 1860 to 1870"], in Revista Aromânească [Aromanian Review] 1, 1 (1929)

PAPACOSTEA, Victor, "Documente aromâneşti dintre 1860 şi 1870" ["Aromanian Documents from 1860 to 1870"], in Revista Aromânească [Aromanian Review] 1, 2 (1929)

PAPAHAGI, Valeriu, Moscopole: Metropola comercială şi culturală a românilor din Peninsula Balcanică in secolul al XVIII-lea [Moschopolis: The Commercial and Cultural Metropole of the Romanians of the Balkan Peninsula in the XVIIIth Century] (Roşiorii de Vede: Tipografia "Lumina Poporului", 1939) 
PEYFUSS, Max Demeter, "Aromânii în era naționalismelor balcanice" ["The Aromanians in the Era of Balkan Nationalisms"], in Aromânii: istorie, limbă, destin [The Aromanians: History, Language, Destiny], ed. Neagu Djuvara (Bucureşti: Editura Humanitas, 2012)

PEYFUSS, Max Demeter, Chestiunea aromânească: evoluția ei de la origini până la Pacea de la București (1913) şi poziția Austro-Ungariei [The Aromanian Question: its Evolution from its Origins to the Peace of Bucharest (1913) and the Stance of Austro-Hungary] (Bucureşti: Editura Enciclopedică, 1994)

PINETTA, Mihail, Apostol Margarit (Iaşi: 1940)

SARAMANDU, Nicolae, La Romanité Orientale (Bucureşti: Editura Academiei Române, 2008)

SHAW, Stanford J. and E.K. Shaw, History of the Ottoman Empire and Modern Turkey, vol. II (Cambridge University Press, 1976 and 1977)

STEPHANOPOLI, Jeanne Z., Trente deux ans de propagande roumaine en Macédoine. Les Koutzovlaques et l'Hellénisme (Athènes: 1903)

STREIT, Georges, L'affaire Zappa. Conflit greco-roumain (Paris: 1894)

TRIFON, Nicolas, Les Aroumains, un people qui s'en va (La Brussière: Editions Acratie, 2005)

TUDORANCEA, Radu, "The Macedo-Romanian Question Within Romanian-Greek Relations in the Early Twentieth Century (1900-1913)", in Historical Yearbook (Bucharest: Romanian Academy, "Nicolae Iorga" History Institute, Volume I, 2004)

ȚOVARU, S., Problema şcoalei româneşti din Balcani [The Issue of Romanian Schooling in the Balkans] (Bucureşti: 1934)

VELICHI, Constantin, "Les relations roumano-grecques pendant la période 1879-1911", in Revue des Etudes Sud-Est Européennes 7, 3 (1969)

ZBUCHEA, Gheorghe, O istorie a românilor din Peninsula Balcanică (secolele XVIII-XX) [A History of the Romanians of the Balkan Peninsula (XVIIIth - XIXth Centuries)] (București: Ed. Biblioteca Bucureştilor, 1999) 
